\title{
THE IMPACT OF IMPLEMENTATION OF A JOINT LIABILITY SYSTEM ON MEMBER BEHAVIOR
}

\author{
(Case Study in Setia Bhakti Wanita East Java, Women's Cooperatives) \\ Iwang Suwangsih ${ }^{1}$, Nuzulul Fatimah ${ }^{2}$, Noneng Rukayah Sukatmadiredja ${ }^{3}$, Emmywati $^{4}$ \\ 1,2,3,4 Management Study Program of Mahardhika, Institute of Economic Science \\ Surabaya,
}

\begin{abstract}
This study analyzes the impact of the consistent implementation of a joint liability system in cooperative life. This research uses descriptive qualitative research methods using indepth interview techniques which are then carried out by open coding to find patterns and theories related to the results of the interviews. As said by Miles \& Huberman (1992: 19) there are three stages that must be done in analyzing qualitative research data, namely (1) data reduction; (2) exposure data (data display); and (3) drawing conclusions and verification (conclusion drawing / verifying). The results of the analysis of this study that have been carried out, explain that cooperative members who implement and obey the rules that exist in joint liability cooperatives unconsciously have an impact on their behavior changes, they have discipline and a high sense of solidarity towards other members.
\end{abstract}

Keywords: Women's Coperatives, Group, Joint Liability System, Organizational culture, Behavior Change

\section{INTRODUCTION}

Women's cooperatives are one type of cooperative classified based on their membership, where all members are women. Based on the Online Data System (ODS) of the Ministry of Cooperatives and SMEs until April 20, 2018, there are 13,212 active female cooperative units and 4,631 have received a Cooperative Identification Number (NIK) certificate. The large number of women's cooperatives was supported by the government, even the governor of East Java initiated the birth of 8,008 women's cooperatives in all urban villages in East Java with the aim of empowering the potential of women in improving the economy of their families.

In managing their businesses, there are women's cooperatives that use a joint liability system to secure cooperative assets. And currently many organizations are trying to form joint liability groups because by implementing joint liability it is proven to be able to secure cooperative assets with $0 \%$ arrears(Arifin, 2008). In addition, the 
implementation of joint liability can foster a sense of solidarity and mutual responsibility, creating a control mechanism (Wahyudi \& Rustantia, 2017).

A Joint Liability System is a system used to manage cooperative businesses. The idea of joint liability originated from the inspiration of Mrs. Mursia Zaafril Ilyas, who had been working to empower Indonesian women by establishing a woman association since 1954. This association then developed into a savings and loan association which was implemented under a responsibility system and became a pre-cooperative with the name "Setia Budi Wanita. ", Then on December 30, 1977 the pre-Setia Budi Wanita Cooperative was inaugurated into a cooperative that was a legal entity and the system of responsibility changed to a joint liability system.(Çriana, 2013).

In the following year, namely on 1978, Mrs. Zaafril expanded her wings to form a women's cooperative which also implemented a joint liability system and was named the female cooperative Setia Bhakti Wanita Surabaya. In its journey, the Setia Bhakti Wanita women's cooperative or better known as the SBW Surabaya cooperative has developed more rapidly than the Setia Budi Wanita cooperative (Koperasi SBW Malang). In 2006, the SBW Surabaya women's cooperative using the joint liability system has consistently grown rapidly with the number of members reaching above 10,000 so that its working area has been expanded to the provincial level and its name has changed to the SBW East Java women's cooperative (Supriyanto, 2009).

According to Supriyanto (2009) joint liability is joint responsibility among members of a group for all obligations towards cooperatives on the basis of openness and mutual trust. In the implementation of joint liability in the group, all decisions are the responsibility of the group so that the group must deliberate if it will decide all decisions such as admission of new members, member loans and so on. Over time the implementation of joint responsibility consistently without realizing it turns out that there is a process of changing member behavior, namely behavior that is based on the values of collective wisdom / values, namely there are values of togetherness, honesty and openness, mutual trust, deliberation, discipline and responsibility. (Supriyanto, 2009).

According to Wikipedia, human behavior is a set of behaviors that are owned by humans and are influenced by customs, attitudes, emotions, ethics, power, and / or genetics. The things that influence a person's behavior are partly located in the individual himself, which are also called internal factors. Some of them are located outside themselves or are called external factors, namely environmental factors. Meanwhile, according to Bohar Soeharto, behavior is the result of the teaching and learning process that occurs as a result of his interaction with the surrounding environment caused by personal experiences. Every behavior that exists in humans is influenced by its development and growth. In the development of humans or other creatures, in general, three things can be distinguished, namely the maturation process, the learning process, and the innate or talent process. (Dra. Siti M. Armando, n.d.) 
From the explanation above, this study aims to dig deeper into how the behavior change process occurs in cooperative members as a result of the implementation of the joint liability system in cooperative life.

\section{LITERATURE STUDY}

\section{Women Cooperative}

According to the International Co-operative Alliance (1996), a cooperative can be defined as: "An autonomous association of people who unite voluntarily to fulfill their common economic, social and cultural needs and aspirations through common ownership and democratically controlled enterprises". In Indonesia, cooperatives are economic institutions based on kinship and mutual cooperation, where the purpose of establishing cooperatives is to improve the economic conditions of the people. The principles of kinship and mutual cooperation in this cooperative are very compatible with the culture of the Indonesian nation, so that cooperatives in Indonesia can develop until now (Sitio, 2001: 9).

The existence of cooperatives in Indonesia as the pillars of the Indonesian economy occupies a very important position in the economic system, for this the function and role of cooperatives in Indonesia are protected by law. (Menteri Koperasi dan Usaha Kecil Menengah Republik Indonesia, 1992). There are several types of cooperatives in Indonesia, for example savings and loan cooperatives, consumer cooperatives, producer cooperatives, multi-business cooperatives. While women's cooperatives are a type of cooperative classified based on their membership, all members are women.

The joint liability system is widely used by women's cooperatives in managing their cooperative businesses. The purpose of using this system are to safe assets of cooperatives, because all risks are borne by the group, so the cooperatives that use joint liability system for their membership requirements must be in groups to understand the rights and obligations of each member and all decision-making processes must go through deliberation because of whatever. which decided to be the responsibility of all group members (Faidah \& Dewi, 2014)

\section{Group}

According to Hogg, A., \& Gaffney (2018) is a group of relatively small individuals who interact and meet face to face, for example groups of decision makers, work groups, organizations, and others. Members in a group tend to have common and interdependent goals, and develop a bond of attraction to one another due to the satisfaction of common goals (Festinger, Schachter, \& Back, 1950; Sherif, 1966; Hogg, 1993). As social beings, humans always need each other in living this life, so that almost all activities in this life are carried out in groups, whether playing or working, a world without groups, of course there is no agriculture, no culture, no religion, no there are cities and so on. (Hogg, A., \& Gaffney, 2018) 
A group is a collection of two or more people who depend on each other and work together to achieve common goals, so their performance is simply a collection of partial contributions from all individual group members (Wardhani, 2018). Likewise, groups in women's cooperatives that apply joint responsibility, are groups of people who have different characteristics from one group to another. These groups are heterogeneous in terms of socio-economic, cultural and educational aspects. The existence of these differences is a challenge for cooperative administrators to be able to direct these groups to work together to achieve one cooperative goal, namely the welfare of its members.

Someone joining a group certainly has different reasons, including for selfprotection, survival or to achieve something that they cannot achieve on their own, but only with other people can hope or desire be achieved and can even reduce anxiety (Schachter,1959). Although the reasons for each individual to join a group vary from one member to another, they usually have the same goal. (Walumbwa, Morrison, \& Christensen, 2012).

Likewise, the groups in joint liability cooperatives, they are formed because of their own initiative that already know and trust each other and agree to form groups and are committed to helping each other and working together. They will not accept members if among they do not or do not know her, because if there is a risk it will be a burden to them.

\section{A Joint Liability System}

According to Supriyanto (2009) joint liability is defined as joint responsibility among members of a group for all obligations towards cooperatives on the basis of openness and mutual trust. And as a system if in a group if there are things that deviate or do not meet the requirements, the consequences are borne by all members in the group. With this system, it is expected that there will be a learning process at the member level in a group. In further development, without realizing that in the implementation of the joint liability system, it turns out that there is a process of changing the behavior of members. Behavior which is based on the values of wisdom which are later known as joint responsibility values. The following is the wisdom value system in the joint responsibility system including togetherness, deliberation, honesty and openness, discipline, and responsibility. (Supriyanto, 2009).

\section{Organizational Culture}

In organizations, culture refers to the mix of symbol, language, ideology, belief, ritual and myth, which is unique to every organization (Pettigrew, 1979; Meek, 1988). As said by Schein (1990), organizational culture is defined as a set of beliefs, values, and assumptions that are shared by members of an organization. Such shared values have an influence on the behavior of organizational members as they rely on the values to guide their decisions and behaviors, which further generate an impact on an organization's effectiveness (e.g., Barney, 1986; Tsui et al., 2006; van Riel \& Fombrun,2009). 
Generally, organizational culture theory posits that organizational culture exerts its influence through shaping the behavior of organizational members (Schein, 1990, 2010) (Meng \& Berger, 2019).

Schein (2004) states that organizational culture is a "pattern of shared basic assumptions that a group has learned as it solved its problems of external adaptation and internal integration, that has worked well enough to be considered valid and, therefore, to be taught to new members as the correct way to perceive, think, and feel in relation to those problems"(Maryam Al-Sada, Bader Al-Esmael, 2017) .

The term strong culture describes cultures that have a significant influence on the behaviors and practices of employees. In strong cultures, there is a clear understanding of what the cultural values and norms are. The term weak culture is used to describe cultures where the norms and practices are not well known or are confusing, inconsistent, or not reinforced. Weak cultures are difficult to work in because expectations are unclear and there is little consistency in practices throughout the organization. Strong cultures are generally associated with much higher performance than weak cultures (Jin, Drozdenko, \& DeLoughy, 2013; Mushtaq, Ahmad, \& Tanveer, 2013).

As said by Wallach (1983) cultures was divided into three categories, namely, bureaucratic, innovative and supportive. The culture of any organization, in general, will have elements from these three categories to different degrees:(Maryam Al-Sada, Bader Al-Esmael, 2017)

1. Bureaucratic cultures: characterized by a well-organized and systematic approach with clearly defined responsibilities and authority. Organizations embracing this culture are normally; structured, cautious, ordered, procedural, hierarchical, regulated, solid and power-oriented (Berson, Oreg, \& Dvir,2008; Taormina, 2009).

2. Innovative cultures: creative, result-oriented, pressurized, stimulating, risk taking, challenging, enterprising and driven (Koberg \& Chusmir, 1987; Valencia, Valle $\&$ Jimenez, 2010). This culture focuses on internal systems of organization and on its competitive advantage by encouraging openness to new ideas (Rasool, Kiyani, Aslam, Akram, \& Rajput, 2012).

3. Supportive cultures: trusting, safe, equitable, sociable, relationship-oriented; they t encourage a collaborative atmosphere (Berson et al, 2008; Burke, Sims, Lazzara, $\&$ Salas, 2007). This culture is warm to work in and employs people who are in general helpful and friendly (Wallach, 1983)

\section{Behavior Change}

According to Watson and other experts, they believe that human behavior is the result of genetic inheritance and environmental or situational influences. Behavior is 
controlled by irrational forces. The result of environmental influences that shape and manipulate behavior. Humans are reactive creatures whose behavior is controlled by factors originating from outside, one of which is environmental factors that determine human behavior. According to this theory, people are involved in behavior because they have learned it through previous experiences. (Nahar, 2016).

According to the Trans theoretical Model (TTM), behavioral change consists of five stages (see Table 1). These stages describe people's willingness to change their behavior, ranging from long-term inactive (i.e., in the Precontemplation stage) to longterm active (i.e., in the Maintenance stage).(Vries, Truong, Kwint, Drossaert, \& Evers, 2016)

\begin{tabular}{l|l}
\hline Stage of change & Description \\
\hline Precontemplation $(P C)$ & $\begin{array}{l}\text { The individual is not willing to change in the foreseeable future (measured as the next 6 months). Individuals in this stage are } \\
\text { mostly uninformed or demoralized. } \\
\text { Contemplation }(C)\end{array}$ \\
$\begin{array}{l}\text { The individual is willing to change in the next } 6 \text { months. Individuals in this stage are aware of some pros of behavior change, } \\
\text { but are still more inclined to value the cons. } \\
\text { The individual is willing to change in the foreseeable future (measured as the next month) and has already taken some small } \\
\text { steps towards change (in the past year). Individuals in this stage usually have some plan on how to tackle this inactiveness. } \\
\text { The individual has changed, but not longer than } 6 \text { months. Individuals in this stage have 'changed', but have not reached the } \\
\text { duration which exemplifies real behavior change. } \\
\text { The individual has changed, longer than } 6 \text { months. Individuals in this stage have changed and are working not to relapse. }\end{array}$ \\
\hline
\end{tabular}

$$
\text { Table } 1 \text {. The stages of change with a short description. }
$$

\section{RESEARCH METHODS}

\section{Research design}

This study uses a qualitative research design with a case study approach. According to Moleong (2009: 6) qualitative research is research that intends to understand phenomena about what is experienced by research subjects such as behavior, perception, motivation, action, etc., holistically, and by means of descriptions in the form of words and languages, in a special natural context and by utilizing various natural methods.

Qualitative research methods are used to obtain in-depth data. The results of qualitative research put more emphasis on meaning than on generalization. The case study is a detailed qualitative research model about a particular individual or social unit during a certain period of time. On a deeper level, a case study is a comprehensive, intense, detailed and in-depth model and is more directed towards an attempt to examine problems or phenomena that are contemporary (time-limited). (Herdiansyah,2010: 76)

\section{Data collection technique}

Data collection techniques are the most strategic step in research. Data is something that is obtained through a data collection method that will be processed and analyzed with a particular method which will then produce something that can describe or indicate something. (Herdiansyah,2010: 116). The data in qualitative research are 
sentences or narratives from subjects or research respondents obtained through a data collection technique which then the data will be analyzed and processed using qualitative data analysis techniques and will produce a finding or research results that will answer research questions submitted.

Data collection techniques of this study are:

1. Observation

observation is an activity in search of data to make a conclusion or analysis. The essence of observation is the existence of visible behavior and the goals to be achieved. Visible behavior can be in the form of behavior that can be seen directly by the eye, can be heard can be counted, and can be measured. (Sugiyono, 2011: 131)

2. In-depth interview

As said by Sugiyono (2015: 74), unstructured or open interviews are often used in opening research or even for more in-depth research on the subjects studied. Unstructured interviews are free interviews where the researcher does not use interview guidelines that have been arranged systematically and completely for the collection of data. The interview guidelines used only outline the issues to be asked. Researchers get direct information with interview techniques from female structural officials in tertiary institutions. As for what is obtained from the acting will be carried out coding using the open coding process of the results of the interview, using Saturate, namely by means of; (coding data is in the attachment) 1) Raw data is given coding for all interview data on each statement from the informant, 2) then from each coding that is formed are grouped into several categories 3) then grouped again into pattern,

3. Study documentation

As said by Sugiyono (2015: 240), the study of documents is a complement to the use of observation and interview methods in qualitative research. This document can be in the form of writings, drawings or monumental works of a person. Documents in the form of writing such as diaries, life histories, stories, biographies, regulations, policies.

\section{Data Validity Techniques}

To get data that can be accounted for imitatively, it is necessary to do the data validity technique. In this research, use triangulation techniques. As said by Sugiyono (2015: 241), there are two types of triangulation as data collection techniques namely triangulation techniques or methods and source triangulation. Test the validity of the data in this study is to use triangulation techniques.. The researcher uses several qualitative data collection techniques, such as observation, interviews, interviews, and documentation for the same data source simultaneously.

\section{Data analysis technique}


As said by Miles \& Huberman (1992: 19), there are three stages that must be done in analyzing qualitative research data, namely; (1) data reduction; (2) data exposure (data display); (3) conclusion drawing and verification (conclusion drawing / verifying). Qualitative data analysis is carried out simultaneously with the data collection process taking place, meaning that these activities are carried out also during and after data collection.

\section{Data Reduction}

The first stage of data analysis is Reducing data, it means brief, selecting the main things, focusing on important things, in search of themes and patterns. It will deliver a clearer picture, and make it easier for researchers to do further data collection. Data reduction can be assisted with electronic equipment such as mini computers, by providing codes on certain aspects. Meanwhile, qualitative data can be simplified and transformed in a variety of ways, such as through rigorous selection, through summaries or brief descriptions, classifying them in a broader pattern, and so on (Sugiyono, 2015: 247)

2. Data Display

After the data has been reduced so the next step is to describe the data (Miles \& Huberman, 1992: 17). Data presentation is used to further improve the understanding of cases and as a reference to take action based on the understanding and analysis of data presentations. By examination the presentations, we will be able to understand what is happening and what needs to be done based on the understanding we get from the presentations. Several types of presentations are matrices, graphs, networks, charts, and so on. Everything is designed to combine information that is arranged in a coherent form and easy to achieve.

3. Conclusion drawing and verification

As said by Miles and Huberman (1992: 18) the third step in qualitative data analysis is drawing conclusions and verification. Extraction of conclusions is the result of research that answers the focus of research based on the results of data analysis.

FINDINGS OF ANALYSIS RESULTS
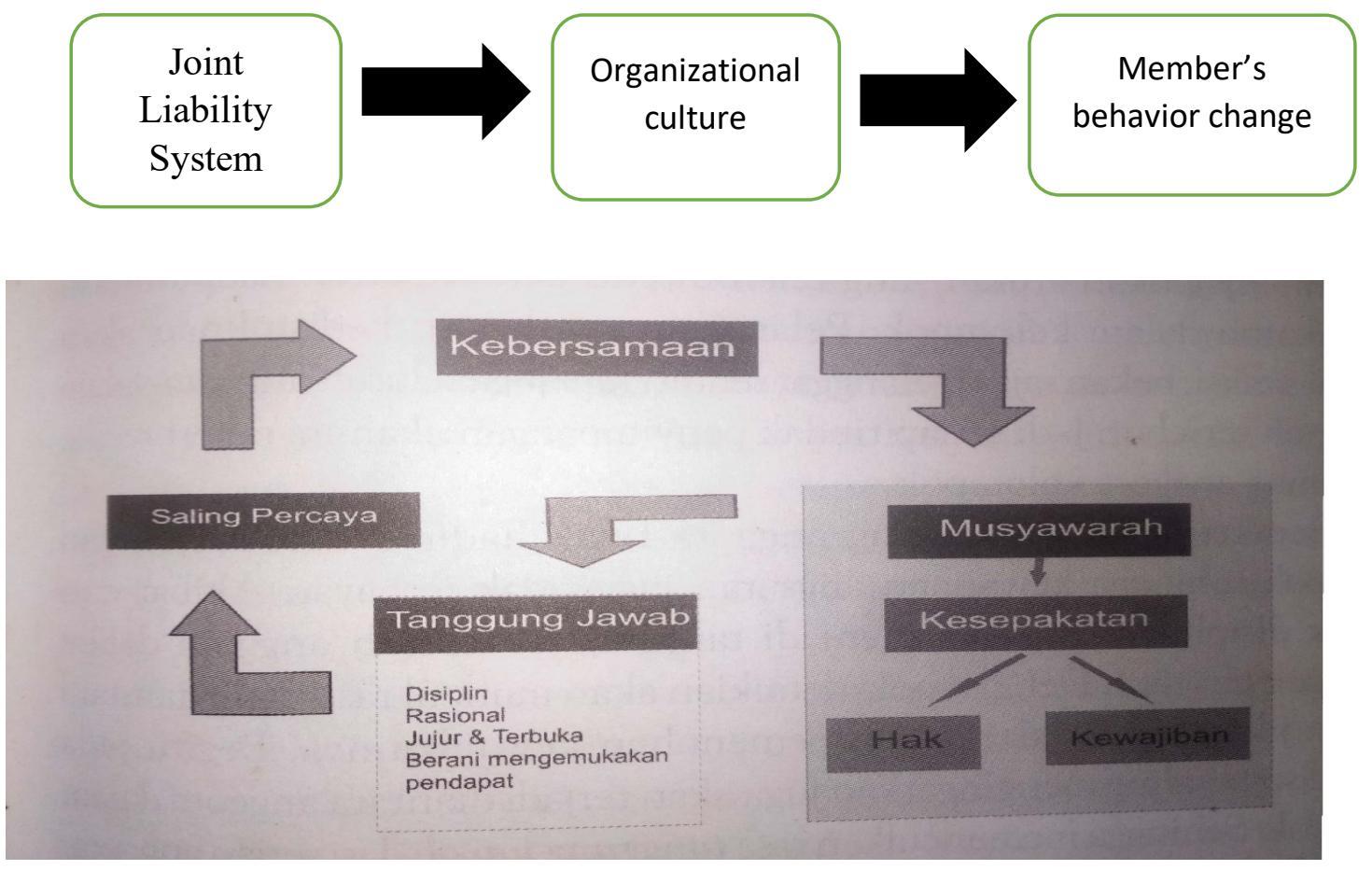
(Supriyanto,2009)

In implementing the joint liability system, there are three elements that must be fulfilled, namely; (Supriyanto, 2009)

1. Group, it means a collection of several members formed by the initiative of these members based on emotional closeness, they already know each other. The existence of this group must be proven by the existence of group meeting activities that are held regularly every month.

2. Obligations, it means that all cooperative members are obliged to actively participate in cooperatives in the form of capital participation, organizational participation, as well as participation in utilizing existing business services in the cooperative.

3. Regulation, it means a rule that must be implemented by all members in maintaining relations between members in the group, as well as maintaining the existence of joint liability groups in carrying out cooperative activities. These regulations include the $\mathrm{AD} / \mathrm{ART}$ of cooperatives, special regulations for cooperatives and group regulations that exist in a group and must not conflict with the regulations set by the cooperative.

The formation of a joint liability group is based on mutual trust among the members. They give each other a belief, that they are people who have high commitment and are responsible, for that if someone will join the group, the group members must already know the prospective member, if no one knows her. then they will not accept the prospective member. Meanwhile, a sense of togetherness arises with regular meetings held every month. In this meeting, they meet and interact with each other.

Mutual trust is a condition in which it contains moralistic contents, such as honesty, or consistency between what someone says and what he does, seriousness and reliable responsibility, good intentions, and nothing to hide. In a trusting relationship, each party believes that all actions to achieve a common goal are highly believed to be welcomed by the support of their peer group. People believe in the goodwill of their peers, believe in their colleagues' ability to perform tasks with all their capabilities, and are reliable.(Sulasmi, 2006)

By implementing the rules in the joint liability system, requiring discipline from each member, they must be on time both in attending group meetings and paying 
obligations because if a member is late in coming to a group meeting and has not entrusted his previous obligations, that member will be the responsibility of all members. members in the group, in other words this member will be jointly borne by the group. In addition to the ministry, members in making decisions such as approving new members and loans must go through a deliberation process. In this deliberation process, the honesty and openness of members in their opinion will determine the quality of decisions. Here, members are required to be brave enough to express their opinions but still in a good way so that the sense of togetherness in the group is maintained and does not bring each other down.

Basically, if the joint liability system is implemented correctly it will foster a rational and responsible mindset. With this pattern there will be a sense of shame among them if they are negligent in fulfilling their obligations. The existence of control and reminding each other will create a sense of responsibility from each member to the existence of herself and her group. (Yayuk Sri Rahayu, 2009). Shame when borne jointly changes the behavior of members to be more disciplined and responsible.

The regulations that exist in the joint liability system must be implemented by all components in the cooperative, be it the management, supervisor, or members, because if one of the parties violates it, the system will not work properly. The management of the cooperative as the manager of the cooperative must always provide motivation to members to be disciplined in the existing rules so that the goals of the cooperative are achieved, namely the welfare of members, because by being able to secure the assets of the cooperative, the cooperative will be able to provide services to members well, the needs of members will be met.

By carrying out a joint liability system in cooperative life continuously with high commitment so that the system indirectly becomes the organizational culture of the cooperative. Culture can be built by design or default. In other words, culture can either be built in a purposeful way or left to chance.(Warrick, 2017). The joint liability system has become an organizational culture, so all components in the cooperative must act according to the existing culture, if there are cooperative members who do not want to do so in accordance with the prevailing culture, these members will get sanctions or even leave the organization.

The sense of togetherness and mutual trust that has arisen since the formation of the group and the interactions that are carried out routinely at each group meeting gradually makes the emotional bonds among the members of the group stronger. They with high awareness of mutual care for the condition of their group and if any of them are experiencing a disaster so they cannot pay their obligations to the cooperative they voluntarily help by jointly lending these members for their obligations to the cooperative, they also provide motivation and even venture capital to overcome the difficulty their friend was having. It means that the sense of solidarity between them is quite high. 
Besides that, every decision making when accepting new members or giving approval for a member loan application must always go through a deliberation process and all members in one group have the same right to express their opinion. This made the members who were previously afraid or embarrassed to speak in public, but gradually they were motivated to speak up to express their opinion.

\section{CONCLUSION}

The result showed that strong culture describes cultures that have a significant influence on the behaviors and practices of employees. In strong cultures, there is a clear understanding of what the cultural values and norms are (Jin, Drozdenko, \& DeLoughy, 2013; Mushtaq, Ahmad, \& Tanveer, 2013). A joint liability system in Women's Coperative Setia Bhakti Wanita is not only used as a system to manage cooperative business but also used as an organizational culture so all of cooperative activities always based on a joint liability system. And this organizational culture had influenced on the member's behavior, they became persons who had a high discipline and solidarity.

An organizational culture in Women's cooperative of Setia Bhakti Wanita is included a supportive culture because the members of cooperative are helpful each other as said by Wallach 1983 that supportive culture is warm to work and employs people who are in general helpful and friendly.

\section{REFERENCES}

Arifin, S. (2008). Dinamika implementasi konsep sistem tanggung renteng dan kontribusinya pada tercapainya zero bad debt.Jurnal Keuangan dan Perbankan, Vol. 12, No. 3 September 2008, hal. 517 - 531 Terakreditasi SK. No. 167/DIKTI/Kep/2007. 12(3).

Çriana, S. (2013). Makna Sistem Tanggung Renteng bagi Terjadinya Perubahan Perilaku Ekonomi Anggota Kelompok Pengusaha Pedagang Kecil (KPPK) di Koperasi Wanita Serba Usaha “ Setia Budi Wanita " Jawa Timur. Jurnal Pendidikan Humaniora, 1(3), 265-273. 
Dra. Siti M. Armando, M. (n.d.). Sikap dan Perilaku. Komunikasi Massa Dan Efek Media Terhadap Individu, Psikologi Komunikasi.

Faidah, S. N., \& Dewi, R. M. (2014). Penerapan Sistem Tanggung Renteng sebagai Upaya Mewujudkan Partisipasi Aktif Anggota dan Perkembangan Usaha di Koperasi Wanita Setia Bhakti Wanita Jawa Timur. Jurnal Pendidikan Ekonomi (JUPE), 2(3), 1-15.

Hogg, M., A., H., \& Gaffney, A. M. (2018). Group Processes and Intergroup Relations. In Stevens' Handbook of Experimental Psychology and Cognitive Neuroscience. https://doi.org/10.1002/9781119170174.epcn414

Maryam Al-Sada, Bader Al-Esmael, M. N. F. (2017). Influence of organizational culture and leadership style on employee satisfaction, commitment and motivation in the educational sector in Qatar. EuroMed Journal of Business, 12(2). https://doi.org/10.1108/EMJB-02-2016-0003

Meng, J., \& Berger, B. K. (2019). The impact of organizational culture and leadership performance on PR professionals ' job satisfaction: Testing the joint mediating e ff ects of engagement and trust. Public Relations Review, 45(1), 64-75. https://doi.org/10.1016/j.pubrev.2018.11.002

Menteri Koperasi dan Usaha Kecil Menengah Republik Indonesia. (1992). UndangUndang Republik Indonesia Nomor 25 Tahun 1992. Tentang Perkoperasian, 1-28. https://doi.org/10.1590/s1809-98232013000400007

Nahar, N. I. (2016). Penerapan teori belajar behavioristik dalam proses pembelajaran. 1 .

Sulasmi, S. (2006). PERAN VARIABEL PERILAKU BELAJAR INOVATIF, INTENSITAS KERJASAMA KELOMPOK, KEBERSAMAAN VISI DAN RASA SALING PERCAYA DALAM MEMBENTUK KUALITAS SINERGI. EKUITAS Akreditasi No.55a/DIKTI/Kep/2006, 13(2), 219-237.

Vries, R. A. J. De, Truong, K. P., Kwint, S., Drossaert, C. H. C., \& Evers, V. (2016). Crowd-Designed Motivation: Motivational Messages for Exercise Adherence Based on Behavior Change Theory.

Wahyudi, A., \& Rustantia, F. (2017). Sistem Tanggung Renteng sebagai Strategi Pembiayaan dalam Meningkatkan Kinerja BUMDES yang Bankable pada Masyarakat Desa ( Studi Fenomenologi pada Laporan Keuangan BUMDES Cipta Karya Desa Ngeni Kabupaten Blitar per Agustus 2016 - Agustus 2017 ). Prosiding Seminar Nasional Dan Call for Paper Ekonomi Dan Bisnis (SNAPER-EBIS) 2017, 2017, 35-40.

Walumbwa, F. O., Morrison, E. W., \& Christensen, A. L. (2012). Ethical leadership and group in-role performance: The mediating roles of group conscientiousness and 
group voice. Leadership Quarterly, 23(5), 953-964.

https://doi.org/10.1016/j.leaqua.2012.06.004

Warrick, D. D. (2017). What leaders need to know about organization culture. Business Horizons. https://doi.org/10.1016/j.bushor.2017.01.011

Yayuk Sri Rahayu. (2009). Penerapan Sistem Tanggung Renteng Pada Koperasi Wanita Serba Usaha "Setia Budi Wanita" Malang. Iqtishoduna, Jurnal Ekonomi Dan

Bisnis Islam, 5(2), 1-15. https://doi.org/DOI: https://doi.org/10.18860/iq.v4i2.291

https://id.wikipedia.org/wiki/Perilaku_manusia 